\title{
Developing A Conceptual Design of Transit-Oriented Development To Improve Urban Land Use Planning
}

\author{
Mohd Ali Berawi ${ }^{1 *}$, Bernard Elpetino Ibrahim $^{1}$, Gunawan ${ }^{1}$, Perdana Miraj ${ }^{1,2}$ \\ ${ }^{1}$ Civil Engineering Department, Faculty of Engineering, Universitas Indonesia, Depok 16424, \\ Indonesia \\ ${ }^{2}$ Civil Engineering Department, Faculty of Engineering, Universitas Pancasila, Jakarta \\ 12640, Indonesia
}

*maberawi@eng.ui.ac.id

Received : 1 December 2018 Final Version Received: 29 April 2019

\begin{abstract}
Transit-oriented development (TOD) is an urban development approach that integrates transit stations to establish transit-oriented behavior. It is a systematic approach to reduce automotive dependency by facilitating increased accessibility to diverse destinations within walking distance. Indonesia has recently adopted this development approach. This paper is intended to provide academic insight into the current Indonesian implementation of TOD. A comparative model is created based on benchmark studies and research on current TOD principles and theories. Based on a comparative analysis between the model and current developments, Indonesian TOD can benefit from further development area and arrangement adjustment to conform to TOD design planning principles.
\end{abstract}

Keywords: Conceptual design, Land use, TOD, Urban development

\section{INTRODUCTION}

Transit-oriented development (TOD) has attracted the interest of city planners and researchers in recent years (Papa \& Bertolini, 2015). TOD is a form of development intended to functionally integrate transit and surrounding developments (Knowles, 2012). TOD is often perceived as an effective means to combat the problems caused by automotive use. Transportation has historically influenced urban development patterns (Ratner \& Goetz, 2013). The increasing ownership of private vehicles has encouraged urban sprawl and congestion in cities worldwide (Knowles, 2012; Negara, 2015). With the emphasis on transit, TOD is often implemented to reduce the use of non-renewable vehicles.

TOD has been successful in urban development in the US (Ratner \& Goetz, 2013). Historically, American cities have grown as a result of increased automotive use. However, there has been a shift in the development approach that favors walkable and sustainable development. Yet, TOD is not a particularly new phenomenon. For example, there was a close correlation between transit and property development in Europe even before the popularity of private vehicle ownership (Knowles, 2012). Currently,
TOD is being implemented in the urban development of many cities (Knowles, 2012; Kwon, 2015; Cervero \& Murakami, 2009).

Recently, Indonesia's capital city of Jakarta has undergone significant infrastructure development, and new transit systems are currently being constructed. Jakarta is notorious for its traffic problems caused by ever-increasing automotive ownership. The paradigm of automotive use must be shifted to favor public transportation systems (Khafian, 2013; Susantono \& Berawi, 2012). With the impending availability of a new transit network and the need to reduce traffic, TOD should be proposed as part of the transit network.

Currently, light rail transit (LRT) is being implemented as one of the transit systems in Jakarta as phase 1 of the construction of the transit network. This phase includes an LRT network connecting East Jakarta and Bekasi. Several TOD plans have been disclosed for select transit stations. This research uses four transit stations-East Jakarta 1, East Jakarta 2, Bekasi 1 and Bekasi 2-as a case study to evaluate the potential for TOD. The results can be used as a benchmark for implementing similar TOD in domestic and foreign projects. 


\section{TOD CHARACTERISTICS}

TOD is a broad term often used to refer to any development around transit stations. A common aspect of TOD is limiting development to within a certain distance. Calthorpe (1993), who coined the concept of TOD, determined that TOD should be within a 2000-foot or five-minute walking distance of a transit stop. This is to ensure walkability and accessibility within the development. However, cities around the world have different development policies regarding TOD perimeters. Hale (2014) argues that the term TOD should be reserved for development with a considerable degree of sustainable travel behavior. He states that many so-called TODs have failed to deliver a transit-oriented outcome, saying that a 'true' TOD should be able to stimulate transit-oriented behavior among inhabitants. It should provide a livable neighbourhood where transit and amenities are within walking distance and thus minimize the necessity of automotive use. Research has revealed that the development of a built environment, particularly a TOD, influences travel behavior. Arrington and Cervero (2008) look at TOD literature and the actual performance of 17 TOD projects. They conclude that TOD commuters typically use transit two to five times more than other commuters in the region. Nasri and Zhang (2014) state that people living in TOD areas in the US have fewer car trips compared to those living in non-TOD areas. According to Cervero and Kockelman (1997), three aspects of urban development in particular influence travel behavior-density, diversity and design. Ewing and Cervero (2010) state that the variables of destination accessibility and distance to transit require further evaluation visà-vis TOD.

This paper examines relatively successful TODs and Cervero's 'D variables' in each development. Three TOD properties are examined as benchmarks. The first is Union Square, a 13.54-hectare mixed-use development with an integrated transit station in the Kowloon area of Hong Kong. The second is Namba Parks located adjacent to Sekai Station in Osaka, Japan that comprises 3.37 hectares of shopping arcades and other amenities. The third is D-Cube City in Seoul, South Korea that comprises a 6.36hectare complex of amenities with direct access to Shindorim Station. These sites were selected due to their different development scales and data availability.

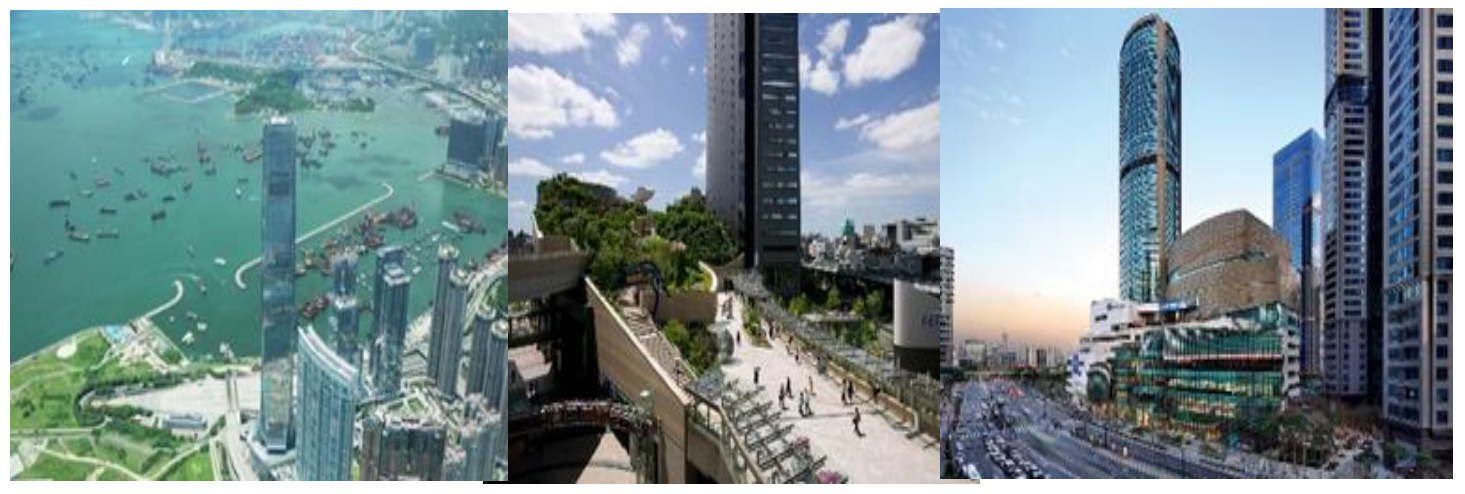

Fig.1: Union Square in Hong Kong, Namba Parks in Osaka, Japan and D-Cube City in Seoul, South Korea (Hong Kong Extra, 2017; Jerde, 2003; Jerde, 2011)

\section{METHODOLOGY}

The data to obtain insight on TOD projects in Jakarta were gathered from news articles, reports and correspondence and were validated during discussion meetings with project contractors. To gauge how well Indonesian TODs have conformed with TOD principles, benchmarks are needed for comparison. We utilize several data sources to attain benchmark references, such as papers, reports, websites and articles, to construct a benchmark model (Rahman \& Berawi, 2001; Rahman \& Berawi, 2002; Berawi et al., 2016). Illustrations and diagrams are created based on literal descriptions, existing examples in articles and aerial images extracted from Apple Maps v2.0 for macOS (data provided by TomTom). The findings are then compared to current Indonesian TOD plans to determine deviations from the benchmarks. If a considerable variation from benchmarks is found, an improved conceptual design is proposed for the current model. 


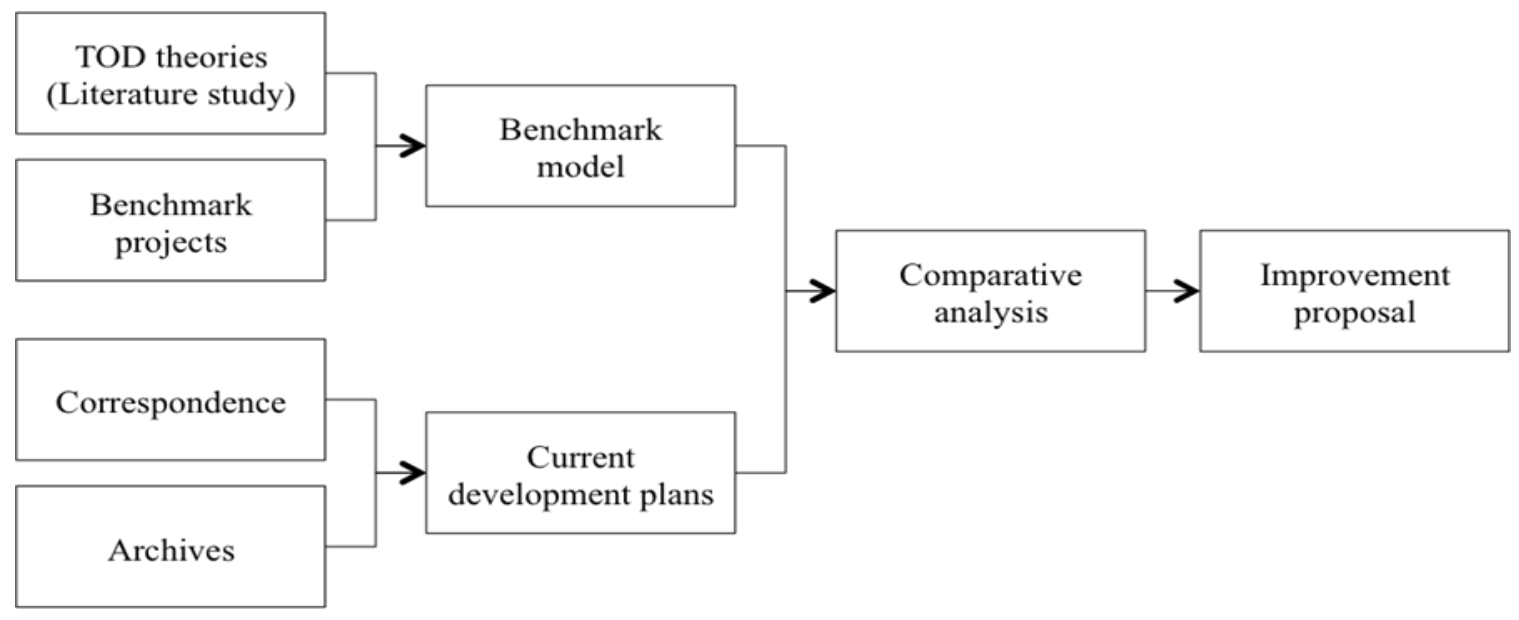

Fig. 2: Research work flow

\section{DISCUSSION AND RESULTS}

\subsection{CHARACTERISTICS ANALYSIS}

\subsubsection{DENSITY}

Density is measured by a specific variable per unit of area. The variable may be population, number of households, activities or number of physical buildings. In a study of Hong Kong's rail and property development, Cervero and Murakami (2009) use floor area ratio (FAR), also called plot ratio, to gauge density. FAR is the ratio of a building's total floor area to the overall size of the land upon which the building stands; the formula to calculate this is FAR (\%) $=($ total floor area $) /($ site area $) \times 100($ Sekai Property, 2016). In this paper, FAR is presented with a decimal value; for example, $250 \%$ is shown as 2.5. Typically, a high FAR value reflects tall buildings. However, parts of buildings may also be underground. FAR may be used to measure the amount of usable space generated in a particular development. The site areas, gross floor areas (GFAs) and FARs of each TOD are summarized in Table 1.

\begin{tabular}{c|ccc}
\multicolumn{4}{c}{ Table 1. TOD areas } \\
\hline & $\begin{array}{c}\text { Union } \\
\text { Square }\end{array}$ & $\begin{array}{c}\text { Namba } \\
\text { Parks }\end{array}$ & $\begin{array}{c}\text { D-Cube } \\
\text { City }\end{array}$ \\
\hline $\begin{array}{c}\text { Land } \\
\text { area } \\
\mathrm{m}^{2}\end{array}$ & 135,400 & 33,700 & 63,600 \\
$\begin{array}{c}\text { GFA } \\
\mathrm{m}^{2}\end{array}$ & $1,090,026$ & 243,800 & 418,140 \\
FAR & 8.05 & 7.23 & 6.57 \\
\hline
\end{tabular}

\subsubsection{DIVERSITY}

Diversity is a characteristic suggested by some activities or uses that are accommodated in a given area. A more and various activities can be accommodated, the better the ability of one development to meet the needs of its residents . Union Square, Namba Parks and D-Cube City at least include residential, commercial and office space. A comparison of each location follows.

Table 2. Land use in the benchmark TOD

\begin{tabular}{c|ccc}
\hline & $\begin{array}{c}\text { Union } \\
\text { Square } \\
\mathrm{m}^{2} \\
\text { (percent) }\end{array}$ & $\begin{array}{c}\text { Namba Parks } \\
\mathrm{m}^{2} \text { (percent) }\end{array}$ & $\begin{array}{c}\text { D-Cube City } \\
\mathrm{m}^{2} \text { (percent) }\end{array}$ \\
\hline Residential & $\begin{array}{c}608,026 \\
(56 \%)\end{array}$ & $60,000(24 \%)$ & $110,300(26 \%)$ \\
Office & $\begin{array}{c}231,778 \\
(21 \%\end{array}$ & $60,000(24 \%)$ & $24,480(6 \%)$ \\
Hotel & $\begin{array}{c}167,472 \\
(15 \%)\end{array}$ & - & $18,360(4 \%)$ \\
Retail/ & $\begin{array}{c}82,750 \\
(8 \%)\end{array}$ & $86,000(34 \%)$ & $107,800(25 \%)$ \\
Commercial & & & \\
Other & - & $44,700(18 \%)$ & $171,000(39 \%)$ \\
Total GFA & $1,090,026$ & $243,800(100 \%)$ & $418,140(100 \%)$ \\
\hline
\end{tabular}

\subsubsection{DESIGN}

According to Cervero and Kockelman (1997), the design is measured by the quality of a network grid, including block size and number of intersections. The design should encourage walking by providing walkways for easy navigation and movement. The dense mixed-use nature of the TODs resulted in several integration solutions. All TODs are built with direct pedestrian access from transit stations, 
with each development having a unique configuration. Namba Parks and D-Cube City are connected to transit stations by common areas or public parks. Hong Kong's Union Square appears to have the most efficient integration. Residential, office and other towers sit atop a commercial platform that also houses the Kowloon transit station. This configuration allows inhabitants to have seamless access to the transit station by walking in a comfortable indoor environment. Similarly, transit users can use the commercial area to navigate the TOD protected from rain and heat.

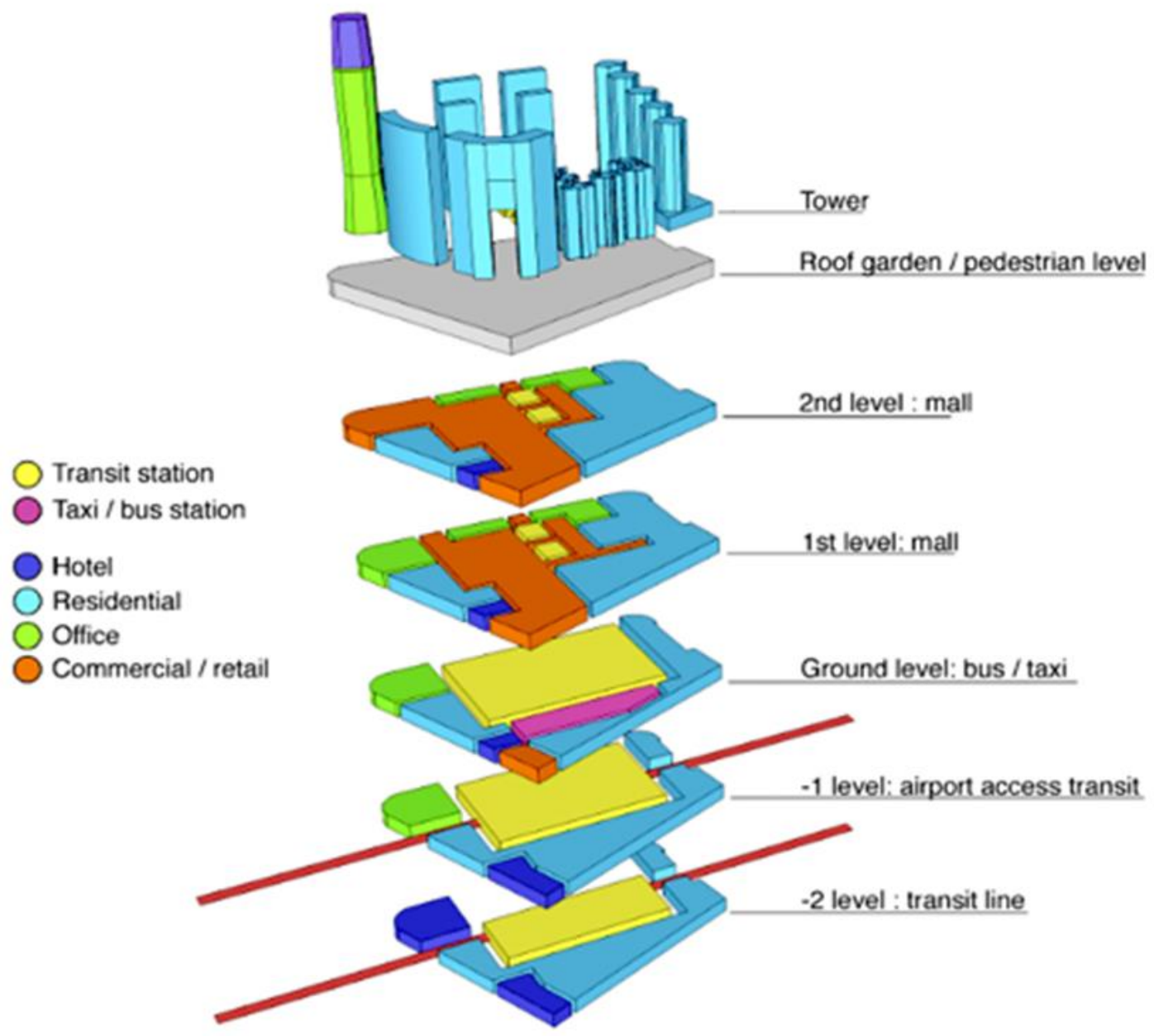

Fig. 3: Union Square's integrated transit station

\subsubsection{DESTINATION ACCESSIBILITY}

Destination accessibility is the level of ease in going to the destination. Destinations may include job locations, landmarks or other attractions. All the benchmark sites are arranged in a way that commercial and working areas are located closest to the transit station. Typically, apartments are placed in the outer radius of the TOD. There is evidence that these TODs are not only activity spaces for local residents but also serve to attract tourists. For instance, from Shindorim Station in Seoul visitors can access facilities in the TOD, such as the retail complex, restaurants and performance centers, that are all within walking distance.
Namba Parks in Osaka is intended to be a natural relief for the surrounding cityscape. People can easily access and wander around the TOD due to its signature canyon and terraced pedestrianoriented design. It is a strong attraction and leads to a number of surrounding developments. With distinct features being offered by each development, the TODs aim to be crowd destinations. With hotels available in or near the TODs, the developments anticipate visitors from outside the TOD community. In the case of Union Square and Namba Parks, both are conveniently accessible from the airport via the transit line. TOD areas themselves are designed to be reasonably accessible by walking. 


\subsubsection{DISTANCE TO TRANSIT}

'Distance to transit' measures the nearest average distance from transit to houses or workplaces. All the TODs studied in this paper are confined within a 400-meter radius from a transit station, with Union Square being the most compact, not exceeding approximately 200 meters. However, a range may not be the only way to express proximity to a transit station, as people rarely walk a straight path en route to a destination from a transit station. The three benchmark TODs all have a commercial area connected to the transit station, thus allowing pedestrians to walk through the building complex instead of around it, which helps keep the actual walking distance down.

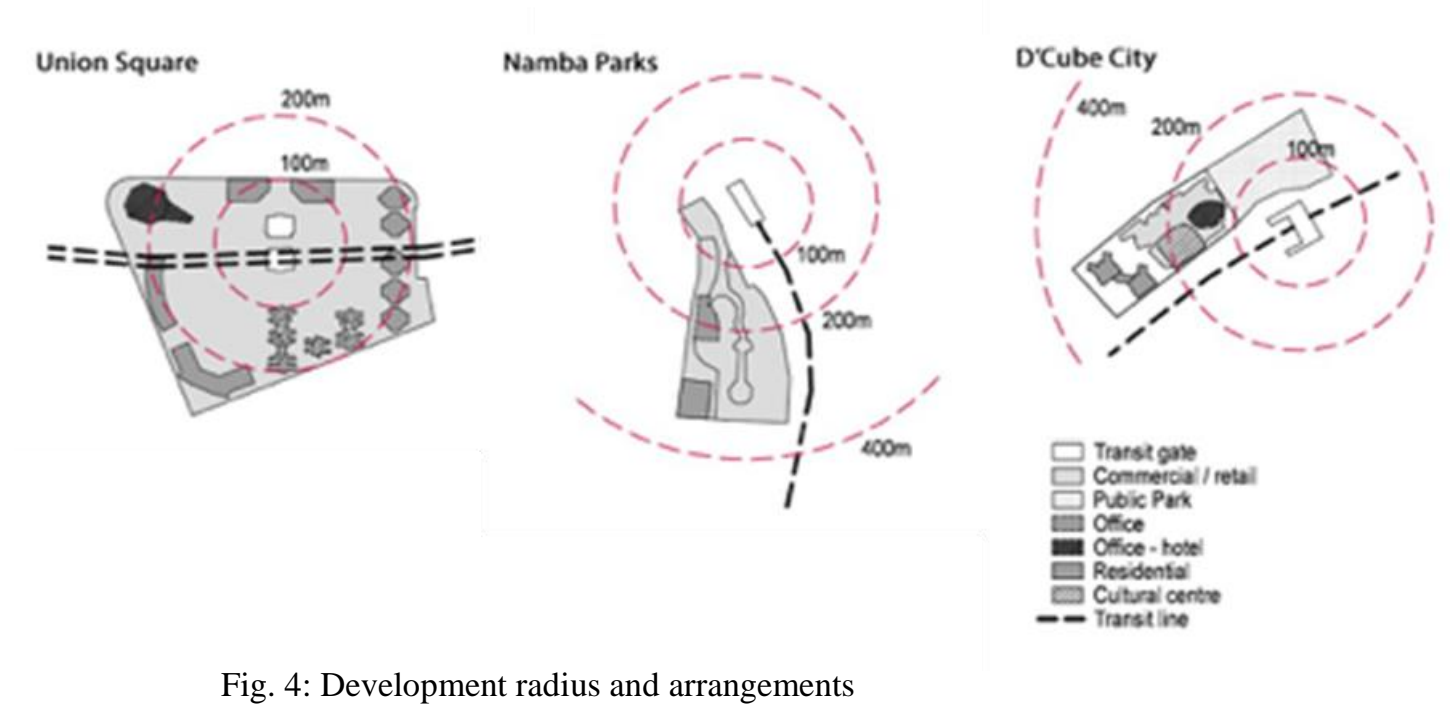

\subsection{BENCHMARK MODEL}

A benchmark model to compare to the current Indonesian TOD is synthesized from properties of Union Square, Namba Parks and D-Cube City. The benchmark model is determined using the mean values of building coverage ratio (BCR) and floor aspect ratio (FAR), as well as the proportion of floor areas used for amenities. The BCR is the ratio of the building area divided by the land size area. The building area is the floor space of a building when looking down from above (aerial view). BCR should not to be confused with FAR, which measures the total floor space in a building. BCR value can be obtained using the formula BCR $(\%)=$ (building area) / (site area) $\times 100$ (Sekai Property, 2016). Common amenities found in the benchmark TODs are residential, office, commercial/retail and hotels. The benchmark model has a BCR value of $92 \%$ and a FAR value of 7.29; floor area usage is summarized in Figure 5.

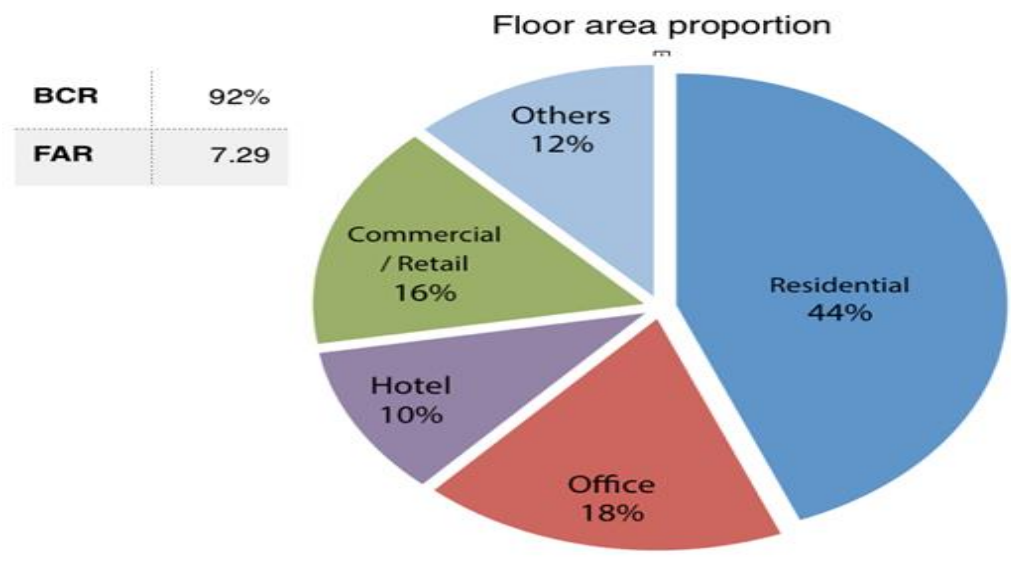

Fig. 5:Benchmark model 


\subsection{TOD PLANNING IN INDONESIA}

As of now, TOD developments in Indonesia have yet to indicate density measurements, reflected by a BCR below $50 \%$. Meanwhile, the benchmark TODs show a BCR of at least $80 \%$ (Namba Parks). The FARs of the Indonesian TODs are lower than 5 . The density comparison can be seen in Table 3 .

Table 3. Density comparison

\begin{tabular}{c|ccccc}
\hline & $\begin{array}{c}\text { Benchmark } \\
\text { (mean) }\end{array}$ & $\begin{array}{c}\text { East } \\
\text { Jakarta } \\
1\end{array}$ & $\begin{array}{c}\text { East } \\
\text { Jakarta } \\
2\end{array}$ & $\begin{array}{c}\text { Bekasi } \\
1\end{array}$ & $\begin{array}{c}\text { Bekasi } \\
2\end{array}$ \\
\hline BCR & $92 \%$ & $30 \%$ & $20 \%$ & $26 \%$ & $20 \%$ \\
FAR & 7.29 & 3.71 & 2.35 & 2.63 & 3.56 \\
\hline
\end{tabular}

TODs in Indonesia are typically developed and sold only as apartment building complexes. Most floor areas are used for residential purposes. In addition to a lack of diversity, the current development also shows a lack of destinations. Such development only address the inhabitants' need for housing. Moreover, without the workplace and commercial areas within the transit network, people would require another form of transportation to reach work locations and other daily activities. This will potentially discourage the use of transit and instead promote the use of private vehicles. With a relatively low $\mathrm{BCR}$, the apartment complex development is also planned in a sparse block plan with gaps between towers, although in some projects the towers are connected by the retail podium, a disjoint among building blocks commonly found weaved together by roads designed for cars. This may discourage pedestrians from walking around the site.

Based on the above observations, it is concluded that the TODs in Indonesia have failed to fulfill the density and diversity requirements. The space within buildings designed to accommodate cars, to navigate the site or for outdoor parking. It is counterintuitive to the common goal of TOD of discouraging automotive use within TODs. Although most TODs in Indonesia are developed within a 200-meter radius around a transit station, the actual distance pedestrians must traverse to navigate the sites is still debatable. Station and TOD's property development are not integrated and should be appropriately designed to accommodate the quality of people movement.

\subsection{LESSON LEARNED AND IMPROVEMENT}

Successful TOD projects often feature dense development reflected by high BCR and FAR values. Density enables flexibility in accommodating diverse amenities on relatively limited urban land plots. Well-designed dense developments benefit inhabitants by keeping everything within walking distance. The benchmark comparison with other TOD projects revealed a BCR value of $92 \%$ and a FAR value of 7.29. Applying this pattern to the current Indonesian TOD plans will significantly increase the floor areas. This improvement may benefit investors by allowing more properties to be developed and sold in the future.

Table 4. Floor area increase

\begin{tabular}{c|ccc}
\hline East Jakarta 1 & BCR & FAR & $\begin{array}{c}\text { Floor } \\
\text { area } \\
\left(\mathrm{m}^{2}\right)\end{array}$ \\
\hline $\begin{array}{c}\text { Current plan } \\
\text { Proposed plan }\end{array}$ & $30 \%$ & 3.71 & 55,588 \\
\hline East Jakarta 2 & 7.02 & 98,760 \\
\hline Current plan & $20 \%$ & 2.35 & 286,710 \\
Proposed plan & $89 \%$ & 7.24 & 888,521 \\
\hline Bekasi 1 & & & \\
\hline Current plan & $26 \%$ & 2.63 & 53,574 \\
Proposed plan & $89 \%$ & 6.87 & 367,980 \\
\hline Bekasi 2 & & & \\
\hline Current plan & $20 \%$ & 3.56 & 178,100 \\
\hline Proposed plan & $90 \%$ & 7.15 & 357,500 \\
\hline
\end{tabular}

With the increased floor areas, Indonesian TODs should include more amenities. In the benchmark model, residential space in the TOD must occupy less than $50 \%$. With the increase of available floor area due to BCR and FAR adjustments, floor area use in Indonesian TODs can be used to accommodate amenities such as those included in the benchmark model. The floor use in each TOD project should be adjusted to be similar to the floor use in the benchmark model. Due to the physical characteristics of each project site, there are slight variations. Residential towers in project 1 in East Jakarta now only take up $46 \%$, down from the previous $90 \%$. It is now closer to the benchmark model's $50 \%$ residential floor area use, allowing for the rest of the space to accommodate offices, more 
commercial areas and hotels. Similarly, after increasing the floor area by adjusting the BCR and FAR, the floor area proportions of the
Indonesian TOD projects better reflect that in the benchmark model. The recommended floor area proportion for each project is shown in Table 5.

Table 5. Proposed floor area proportions

\begin{tabular}{|c|c|c|c|c|c|}
\hline & Residential & Office & Hotel & Commercial/Retail & Others \\
\hline Benchmark model & $44 \%$ & $18 \%$ & $10 \%$ & $16 \%$ & $12 \%$ \\
\hline East Java 1 & $46 \%$ & $18 \%$ & $11 \%$ & $13 \%$ & $12 \%$ \\
\hline East Java 2 & $44 \%$ & $18 \%$ & $10 \%$ & $16 \%$ & $12 \%$ \\
\hline Bekasi 1 & $46 \%$ & $18 \%$ & $10 \%$ & $14 \%$ & $12 \%$ \\
\hline Bekasi 2 & $45 \%$ & $18 \%$ & $11 \%$ & $13 \%$ & $13 \%$ \\
\hline
\end{tabular}

A commercial area as a transition between the transit station and the rest of the development keeps the TOD areas accessible. TOD project can construct those amenities into integrated development area. By utilizing a comprehensive density and diversity design, a pedestrianfriendly and convenient TOD can be achieved. Learning from benchmark TODs, commercial areas can function as a convenient way of integrating the rest of the development. The commercial area can be integrated with the transit station, while towers can be situated above or physically connected in other arrangements. This way, the commercial area can also function as comfortable circulation space between the transit station and the rest of the development.

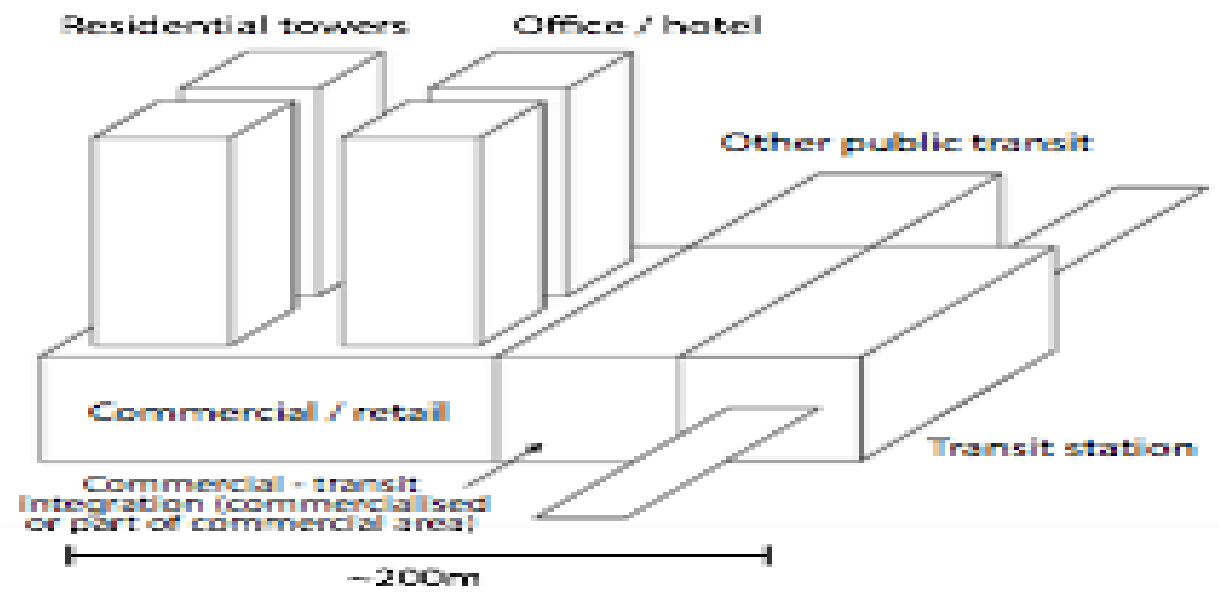

Fig. 6: Proposed development model

Benchmark projects show how density is an indicator of conventional TOD design reflected by efficient BCR and FAR. BCR and FAR allows more efficient land use and the possibility of developing a multi-use project. With an innovative design, density can also contribute to pedestrian accessibility by keeping the amenities within walking distance, thus reducing automotive dependency. Indonesian TODs can start improving project plans by adopting a more efficient BCR and FAR. Currently, Indonesian TODs show little progress in terms of density, diversity, design, destination accessibility and distance to transit. Physical developments have not reflected a dense, diverse or pedestrianoriented design. This is evident by the lack of coherent transit-to-development integration. Moreover, the sparse layout and road construction within the development area prioritizes vehicular access rather than pedestrian walkways, hinting that planning is still favouring a vehicle-centric design.

Based on the previously described TOD benefits, TOD as a new development approach in Indonesia promises advantages over conventional approaches to development. Therefore, policymakers should assess the potential of TOD implementation in Indonesia and become proactively involved in policymaking for better national development growth. Furthermore, future research should develop improved conceptual plans that 
integrate transport service, public facilities and commercialization to further improve the benefits of TOD implementation in Indonesia.

\section{CONCLUSION}

Based on a benchmark comparison, Indonesian TOD plans have yet to conform with TOD principles, as indicated by relatively low BCR and FAR values. By studying the implementation of TOD principals in successful projects, a benchmark model was generated to allow comparative analysis between the benchmark design and current developments. The study revealed the lack of area evident in designs with low BCR and FAR values. By adjusting these values, more useful space would become available to include more developments to result in a design that better conforms to TOD principles. BCR values can be increased up to $90 \%$ from $20 \%$ using the current plan, and the FAR amount can be increased from 2.35 to 7.24. Furthermore, the benchmark model has incorporated comprehensive designs found in other successful projects. The plan includes various amenities in a compact arrangement that ensures accessibility and walkability. Based on these findings, current TODs can benefit from the addition of facilities other than apartments while maintaining compactness and accessibility.

\section{ACKNOWLEDGEMENTS}

This research was supported by grants from Universitas Indonesia and the Ministry of Research and Higher Education, the Republic of Indonesia.

\section{REFERENCES}

Abdul-Rahman, H., \& Berawi, M. A. (2002). Managing change in construction contracting. Contract Management, 42, 1016.

Abdul-Rahman, H., \& Berawi, M. A. (2001). "Power quality system," a new system of quality management for globalization: Towards innovation and competitive advantages. Quality Assurance, 9(1), 5-30.

Arrington, G., \& Cervero, R. (2008). TCRP report 128: Effects of TOD on housing, parking, and travel. Washington, DC: Transportation Research Board of the National Academies.

Berawi, M. A., Miraj, P., Berawi, A. R. B., Silvia, \& Darmawan, F. (2016). Towards self-sufficient demand in 2030: Analysis of life-cycle cost for Indonesian energy infrastructure. International Journal of Technology, 7(8), 1444-1453.

Calthorpe, P. (1993). The next American metropolis: Ecology, community, and the American dream. New York: Princeton architectural press..

Cervero, R., \& Kockelman, K. (1997). Travel demand and the 3 Ds: Density, diversity, and design. Transportation Research Part D: Transport and Environment, 2(3), 199219.

Cervero, R., \& Murakami, J. (2009). Rail and property development in Hong Kong: Experiences and extensions. Urban Studies, 46(10), 2019-2043.

Ewing, R., \& Cervero, R. (2010). Travel and the built environment: A meta-analysis. Journal of the American Planning Association, 76(3), 265-294.

Hale, C. (2014). TOD versus TAD: The great debate resolved...(?), Planning Practice \& Research, 29(5), 492-507. DOI: 10.1080/02697459.2012.749056

Hongkong Extras (2017). Hong Kong observation deck. Retrieved from: http://www.hongkongextras.com/_sky100. html

Jerde. (2003). Namba Parks. Retrieved from: https://www.jerde.com/places/detail/namba -parks

Jerde. (2011). D-Cube City. Retrieved from: https://www.jerde.com/places/detail/dcube-city

Khafian, N. (2013). The efforts of handling transportation problems in DKI Jakarta through sustainable transportation policy. International Journal of Administrative Science \& Organizations, 20(3), 179-185.

Knowles, R. D. (2012). Transit-oriented development in Copenhagen, Denmark From the Finger Plan to Ørestad. Jounal of Transport Geography, 22, 252-261.

Kwon, Y. (2015). Sejong Si (City): are TOD and TND models effective in planning Korea's new capital? Cities, 42, 242-257.

Nasri, A., \& Zhang, L. (2014). The analysis of transit-oriented development (TOD) in Washington, D.C. and Baltimore metropolitan areas. Transport Policy, 32, 172-179.

Negara, S. D. (2016). Building a megacity: Jakarta in the 21 st century a case study of the urban transport system in Jakarta. Review of Indonesian Economic and Business Studies, 6(1), 29-42.

Papa, E., \& Bertolini, L. (2015). Accessibility and transit-oriented development in European metropolis areas. Journal of Transport Geography, 47, 70-83. 
Ratner, K. A., \& Goetz, A. R. (2013). The reshaping of land use and urban form in Denver through transit-oriented development. Cities, 30, 31-46.

Sekai Property. (2016, April). Land use zone in Japan; building coverage ratio and floor area ratio. Retrieved from: https://en.sekaiproperty.com/news/270/land -use-zone-in-japan-building-coverageratio-and-floor-area-ratio

Susantono, B., \& Berawi, M. A. (2012). Perkembangan kebijakan pembiayaan infrastruktur transportasi berbasis kerjasama pemerintah swasta di Indonesia. Jurnal Transportasi, 12(2), 93-102. 